\title{
CMA addresses questions after "frustrating" annual general meeting
}

Cite as: CMAJ 2021 November 8;193:E1705. doi: 10.1503/cmaj.1095972

Posted on cmajnews.com on October 22, 2021

A fter a contentious annual general meeting where measures meant to improve equity and diversity in leadership failed to win a two-thirds majority to pass, the Canadian Medical Association (CMA) hosted a follow-up session to address members' questions and concerns.

CMA Board Chair Dr. Suzanne Strasberg started the meeting by acknowledging members' frustration that "the CMA did not run an effective meeting at our AGM this year."

Many physicians had taken to social media to express disappointment with the proceedings, raising concerns about systemic exclusion in medicine, democratic processes, poor attendance, and technical difficulties.

At the follow-up meeting attended by just 35 members, Strasberg said there were "a number of factors including technical problems, procedural issues, and logistical issues associated with COVID."

According to Strasberg, the CMA board is conducting an in-depth review with the law firm Borden Ladner Gervais to "identify the things that went well and the areas of frustration and failure" to create recommendations for next year's meeting.
In addition to changing the virtual meeting platform, "we need to ensure that participants are better informed about the rules of procedure and that background materials are more accessible," Strasberg said.

"We need more engagement of members in the months before the AGM and more time at the AGM for discussion to hear both sides. And we need to foster a productive and respectful dialogue at our AGM for the good of the profession," she said.

CMA President Dr. Katharine Smart said the CMA remains committed to promoting equity, diversity, and inclusion in medical leadership. She said the current process for nominating the next president-elect underway in British Columbia is an immediate opportunity to advance those goals.

"We've tried to make this more equitable by reaching out to traditionally underrepresented stakeholders to help generate interest, answer your questions, and help bring forward a slate of candidates that truly represents the diversity of our profession," Smart said.

CMA is also working with the executive firm Boyden to expand its outreach to potential candidates from underrepresented groups. The organization hosted a webinar for potential candidates on September 23 and is planning another session for early November.

The call for candidate nominations from British Columbia will remain open until late November and the campaign period begins in early December.

Smart also talked about CMA's progress on climate action after members raised concerns that the COVID-19 pandemic has overshadowed the climate crisis.

Smart said the CMA is considering advocacy to "make the health care system net-zero as the health care system itself is a huge contributor to waste and carbon emissions."

In addition to already fully divesting from fossil fuel companies, the CMA will transition to investing in a portfolio of companies with net-zero greenhouse gas emissions by 2050 .

\section{Diana Duong, CMAJ}

Content licence: This is an Open Access article distributed in accordance with the terms of the Creative Commons Attribution (CC BY-NC-ND 4.0) licence, which permits use, distribution and reproduction in any medium, provided that the original publication is properly cited, the use is noncommercial (i.e., research or educational use), and no modifications or adaptations are made. See: https://creativecommons. org/licenses/by-nc-nd/4.0/ 